(C) 2021 by the authors. This work is licensed under Creative Commons Attribution 4.0 International License https://creativecommons.org/licenses/by/4.0/

\title{
SIMILARITIES AND DIFFERENCES BETWEEN FAMILIAL MEDITERRANEAN FEVER AND BEHÇET'S DISEASE
}

Received: Feb. 5, 2021

Accepted: Feb. 26, 2021

Ummusen Kaya Akca' ${ }^{1}$ https://orcid.org/0000-0002-0426-9432

Ezgi Deniz Batu ${ }^{1 *}$ https://orcid.org/0000-0003-1065-2363

1Department of Pediatrics, Division of Rheumatology, Hacettepe University School of Medicine, Ankara, Turkey

*Corresponding author: Ezgi Deniz Batu, Department of Pediatric Rheumatology, Faculty of Medicine, Hacettepe University, Sihhiye campus 06100 Ankara, Turkey;

Twitter handle: @EzgiDenizBatu1; E-mail: ezgidenizbatu@yahoo.com

\begin{abstract}
Familial Mediterranean Fever (FMF) is the most common monogenic autoinflammatory disease, mainly affecting populations originating from the Eastern Mediterranean region. Behçet's Disease (BD) is grouped in polygenic autoinflammatory diseases. It is a systemic vasculitis that affects all types and sizes of blood vessels. The aim of this article is to shed light on similarities and differences between FMF and BD. BD is frequently reported along the ancient Silk Road, extending from the Far East to the Mediterranean basin. Several studies have searched for the association between FMF and BD. FMF is caused by mutations of the MEditerranean FeVer (MEFV) gene while an increased frequency of MEFV mutations is reported in BD patients. Although BD and FMF share some epidemiological and pathophysiological features, there are distinct clinical characteristics of these nosological entities. Mucocutaneous manifestations, especially recurrent oral ulcers, are the most common symptom in BD patients whereas fever accompanied by serosal inflammation is the main clinical presentation in FMF patients.
\end{abstract}

Keywords: Familial Mediterranean fever, Behçet disease, MEFV gene, COVID-19

How to cite: Akca UK, Batu ED. Similarities and differences between familial Mediterranean fever and Bechet's disease. Cent Asian J Med Hypotheses Ethics 2021;2(1):43-50. https://doi.org/10.47316/cajmhe.2021.2.1.07

\section{ABBREVIATIONS}

Behçet's disease: BD

Familial Mediterranean Fever: FMF

Human leukocyte antigen gene encoding B*51: HLA B51

Endoplasmic reticulum aminopeptidases 1: ERAP1

International Criteria for Behçet's Disease: ICBD

Interleukin: IL

International Study Group: ISG

MEditerranean FeVer: MEFV

Pediatric BD: PEDBD

Toll-like receptors: TLRs

Tumor necrosis factor: TNF

Variants of uncertain significance: VUS

\section{INTRODUCTION}

Familial Mediterranean fever (FMF) and Behçet's disease (BD) are autoinflammatory diseases common in the Mediterranean region. They do share some features and may co-occur in one patient. Distinct characteristics of these diseases make the differential diagnosis easier.

FMF is the most common autoinflammatory disease with autosomal recessive inheritance. It mainly affects populations originating from the Mediterranean region, predominantly Armenians, Turks, Jews, and Arabs [1]. FMF is caused by mutations of the MEditerranean FeVer (MEFV) gene that encodes pyrin. Pyrin acts as a pattern recognition receptor that assembles the inflammasome 
complex [2, 3]. Gain-of-function mutations of MEFV cause pyrin inflammasome activation, leading to an increase in caspase-1 activation and interleukin $1 \beta$ (IL1ß) release [2].

Generally, FMF is characterized by self-resolving inflammatory attacks which last 1-3 days. Patients are usually free of symptoms between attacks. A typical attack consists of fever accompanied by peritonitis, pleuritis, arthritis, erysipelas-like erythema, or rarely by pericarditis [4]. Clinical presentation and course of the disease may differ across various ethnic groups and individuals [5]. Genotype affects the disease phenotype. For instance, M694V homozygotes often present with severe disease, amyloidosis, and frequent attacks, necessitating higher doses of colchicine [6-8]. Also, FMF patients may suffer from other manifestations such as protracted febrile myalgia, spondyloarthropathy, and vasculitic rash [9].

FMF diagnosis is mainly based on clinical presentations. MEFV gene analysis could support the clinical diagnosis. The latest set of FMF classification criteria combines clinical manifestations and genotype [10]. FMF classification is based on the presence of confirmatory MEFV genotype and at least one of the following: duration of attackes lasts 1-3 days, arthritis, chest pain, or abdominal pain. If the patient has non-confirmatory MEFV genotype (compound heterozygous for a single pathogenic MEFV mutation variants and a single mutation variant of uncertain significance (VUS), or biallelic VUS, or heterozygous for a single pathogenic MEFV mutation variant), the presence of at least two of the mentioned parameters is required for FMF diagnosis.

Colchicine is the frontline therapy to suppress inflammation and prevent attacks and complications in FMF [11]. Colchicine resistance, defined as one or more attacks per month during three months or persistent systemic inflammation between attacks, is detected in about $5 \%$ of patients [12-14]. Biological drugs, especially anti-IL-1 agents, are used to treat colchicine resistant/intolerant patients [15].

$\mathrm{BD}$ is a systemic vasculitis with autoinflammatory features. It is frequently reported along the ancient Silk Road, extending from the Far East to the Mediterranean basin [16]. The genetic predisposition to $B D$ is well known, with the human leukocyte antigen gene encoding $B^{*} 51$ (HLA B51) playing a critical role. HLA B51 is not pathognomonic for $B D$ since its positivity reaches $20 \%$ in healthy subjects. This marker simply supports BD diagnosis [17].
Endoplasmic reticulum aminopeptidase 1 (ERAP1) is another enzyme that plays a pathogenic role in $\mathrm{BD}$. It facilitates the processing and delivery of peptides to HLA molecules. The presence of ERAP1 polymorphisms that lead to an unfolded protein response of HLA B51 triggers endoplasmic stress and activates the inflammation via the IL-23/LL-17 pathway.

$\mathrm{BD}$ is a multisystemic disease with heterogeneous clinical presentations. Recurrent oral ulcers are reported in almost all patients with $\mathrm{BD}$, including $87-98 \%$ of them presenting with such symptoms in the disease debut [18]. The lesions are round or oval painful ulcers with erythematous borders located on lips, tongue, cheeks, or palate. Multiple ulcers are common, but single ulcers are also possible. Genital ulcers are reported in $55-83 \%$ of cases as the second most common features of BD [1922]. Genital lesions tend to be deeper with irregular margins and healing with scars.

Cutanenous signs may present as erythema nodosumlike lesions, papulopustular elements, and folliculitis. Pathergy test positivity, which is not pathognomonic for $\mathrm{BD}$, varies widely across cohorts [23].

Ocular involvement may present with anterior and posterior uveitis, or panuveitis. BD uveitis may lead to the loss of vision. Neurological features have a broad clinical spectrum, ranging from isolated headaches, benign elevated intracranial pressure, cerebral venous thrombosis, meningoencephalitis, psychiatric disturbances, cranial nerve palsy, to parenchymal lesions in the brain stem, spinal cord, basal ganglia, and cerebral white matter $[24,25]$.

Vascular involvement can affect all sizes of arterial and venous vessels. Aside from deep vein thrombosis, which is the most common vascular manifestation, superficial vein thrombosis, arterial thrombosis, and arterial aneurysm may also develop [26].

A spectrum of other manifestations has been identified, including articular symptoms, gastrointestinal involvement, pericarditis, myocarditis, pulmonary involvement, and glomerulonephritis [27-29].

Several classification criteria of BD have been proposed [30]. The most widely used sets of criteria for adult patients are those of the International Study Group (ISG) [31] and the International Criteria for BD (ICBD) [32]. According to the ISG, a patient must have oral ulceration and two of the following four parameters for the classification of $\mathrm{BD}$ : genital ulceration, eye manifestations, skin lesions, and positive pathergy test [31]. In the revised ICBD criteria [33], two points were 
scored for genital ulceration, oral aphthosis, and ocular findings, and one point each for skin lesions, vascular lesions, and neurological findings. In the presence of pathergy test positivity, one point was added. A score of four and more points is required for the diagnosis of $\mathrm{BD}$ [34]. The sensitivity and specificity of the most recent version of ICBD is $94.8 \%$ and $90.5 \%$, respectively [34]. All these criteria are developed for adults, and there was a need for a new set of criteria for pediatric BD.

The Pediatric BD (PEDBD) study established the classification criteria for pediatric patients in 2015. Three of the following six items are required to classify a patient as having pediatric $\mathrm{BD}$ : recurrent oral aphthosis (at least three attacks per year), genital aphthosis, skin involvement, ocular involvement, neurological signs, or vascular findings [20]. The sensitivity and specificity of these criteria in pediatric $\mathrm{BD}$ patients have been reported as $91.7 \%$ and $42.9 \%$, respectively, in the validation study.

The management strategy may differ in BD depending on the type and severity of organ involvement. Topical corticosteroids and colchicine are commonly preferred to treat mucocutaneous findings. Other treatment options include systemic corticosteroids, apremilast, azathioprine, anti-Tumor Necrosis Factor-alpha (antiTNF-alpha) agents, cyclophosphamide, cyclosporine A, and interferon $a[18,35]$.

\section{SIMILARITIES BETWEEN FMF AND BD}

FMF is the prototype of the monogenic autoinflammatory diseases while $\mathrm{BD}$ is grouped in polygenic autoinflammatory diseases (Table 1).

Table 1. Distinguishing features of FMF and BD

\begin{tabular}{|c|c|c|}
\hline & FMF & BD \\
\hline Inheritance mode & Monogenic autoinflammatory disease & Polygenic autoinflammatory disease \\
\hline $\begin{array}{l}\text { MEFV gene } \\
\text { mutations }\end{array}$ & Associated with the disease & Increased frequency of mutations \\
\hline Epidemiology & Common in the Mediterranean region & $\begin{array}{l}\text { Common along the ancient Silk Road extending to } \\
\text { the Mediterranean basin }\end{array}$ \\
\hline Pathogenesis & $\begin{array}{l}\text { Increased production of } \mathrm{IL}-1 \beta \text { by the } \\
\text { overactive pyrin inflammasome }\end{array}$ & $\begin{array}{l}\text { An unfolded protein response of HLA-B51 } \\
\text { Association with Toll-like receptors } 2,4 \text {, and } 9 \\
\text { Higher levels of IL-1 } 1 \beta\end{array}$ \\
\hline $\begin{array}{l}\text { Age of disease } \\
\text { onset }\end{array}$ & Early childhood & Late childhood-adulthood \\
\hline Key clinical features & Periodic fever, serositis, arthritis & $\begin{array}{l}\text { Recurrent oral and genital ulceration, uveitis, skin } \\
\text { lesions, neurological and vascular involvement }\end{array}$ \\
\hline Treatment & $\begin{array}{l}\text { Colchicine } \\
\text { Anti-IL-1 treatment in colchicine- } \\
\text { resistant FMF patients }\end{array}$ & $\begin{array}{l}\text { Differ depending on the type and severity of organ } \\
\text { involvement } \\
\text { Colchicine for mucocutaneous findings } \\
\text { Other treatment agents; apremilast, azathioprine, } \\
\text { anti-TNFa agents, cyclophosphamide, cyclosporine } \\
\text { A, interferon a }\end{array}$ \\
\hline
\end{tabular}

Abbreviations: FMF; Familial Mediterranean Fever, BD; Behçet's disease, IL; interleukin, TNF; tumor necrosis factor.

The increased frequency of MEFV mutations in BD patients and the presence of FMF as a comorbidity in BD patients have been demonstrated in several studies [36, 37]. MEFV mutations are reported as susceptibility factors for vascular involvement in $\mathrm{BD}[38,39]$. Coexistence of BD and FMF has also been reported in the literature. Schwartz et al. reported 39 patients with $\mathrm{BD}$ and FMF and stated that response to colchicine treatment was lower among patients with both FMF and BD compared to patients with only FMF [40]. And, skin, central nervous system, and gastrointestinal involvements were more common in patients with FMF and BD compared to patients with only BD [40]. Akpolat et al. also reported a BD patient with homozygous M680I mutations who developed amyloidosis [41]. BD and FMF also share some epidemiological and pathophysiological features. BD is most common along the Silk road, extending from the Far East to Mediterranean basin countries [16]. FMF is also highly prevalent in countries of the Mediterranean basin [42]. On the other hand, IL-1 has a role in the pathogenesis of both FMF and BD. Increased production of IL-1 $\beta$ by the overactive Pyrin 
inflammasome is the central process in FMF pathogenesis [42]. The higher levels of IL-1 $\beta$ were also found in $\mathrm{BD}$ patients with both active and inactive disease compared to healthy controls [43]. Also, Toll-like receptors (TLRs) 2, 4, and 9 have been implicated in BD pathogenesis [44]. The gene polymorphisms of TLR4 and TLR9 were more frequent in $\mathrm{BD}$ patients than in healthy controls $[45,46]$. The interaction of TLR2 and 4 with their ligands cause increased IL- $1 \beta$ production via NLRP3 inflammasome in active BD patients [47, 48]. Colchicine is the mainstay of FMF treatment [42]. It is also frequently used in the treatment of mucocutaneous manifestations of BD [49].

\section{DIFFERENCES BETWEEN FMF AND BD}

FMF phenotype usually becomes apparent in early childhood while the age of onset is older in BD [49]. Fever and recurrent serosal inflammation, which are the main manifestations of FMF, are not prominent in BD. On the other hand, uveitis, vasculitis, and neurological involvement are more specific to BD. Regarding treatment, anti-IL-1 drugs form the primary therapeutic option in treating colchicine-resistant FMF while there are limited data regarding the efficacy of anti-IL-1 drugs in $\mathrm{BD}$ patients. Fabiani et al. reported that 25 of $36 \mathrm{BD}$ patients who used anti IL-1 treatment had a complete response in the 3-month follow-up. Eighteen patients continued treatment for at least 12 months with a response to treatment. However, in the remaining patients, treatment was discontinued within the first year due to the inefficacy [50]. Similarly, anti-IL-1 treatment was administered to nine BD patients, refractory to standard therapies and TNF blockers. A rapid improvement was observed. However, most patients experienced relapse within several months [51].

\section{FMF AND BD DURING THE COVID-19 PANDEMIC}

The COVID-19 outbreak has created a global health crisis. There have been concerns about the influence of COVID-19 on patients with rheumatologic diseases, especially those receiving immunosuppressive therapy [52]. Espinosa et al. reported four BD patients with mild clinical presentations of COVID-19 [53]. Two of them were receiving immunosuppressive agents, and two of them were receiving colchicine [53]. Brito et al. also reported a BD patient with a mild form of COVID-19 who was on anti-TNF treatment $[53,54]$. Currently, there are no strict guidelines regarding the management of immunosuppressive agents during the COVID-19 pandemic. However, it is recommended to continue immunosuppressive therapy unless the infection is present [55]. Bourguiba et al. evaluated the clinical course of 27 patients with COVID-19 in a cohort of 342 FMF patients. They stated that these patients did not appear to have an additional risk factor for severe SARSCoV-2 infection compared to the general population [56]. Similarly, Kobak et al. reported an FMF patient suffering from COVID-19 infection with mild symptoms [57].

Individuals carrying a MEFV mutation might have a selection advantage against plaque $[58,59]$. It is unknown whether the presence of MEFV mutations causes an advantage against COVID-19. Importantly, colchicine has been used in COVID-19. The results of several studies have supported the benefit of colchicine in COVID-19 [60, 61]. In a randomized placebocontrolled trial, colchicine use has been associated with statistically significant reductions in the risk of death and hospitalization compared to placebo $[60,61]$. Current studies do not suggest a decreased or increased risk in $\mathrm{BD}$ or FMF patients for the occurrence of COVID-19 or COVID-19-related complications compared to the healthy population.

\section{CONCLUSION}

BD and FMF share some epidemiological and pathophysiological features. And, MEFV mutations, primarily associated with FMF, are probably genetic susceptibility factors in BD. There are distinct clinical features of both diseases that make the differential diagnosis easier.

\section{AUTHOR CONTRIBUTIONS}

Substantial contributions to the conception or design of the work; and the acquisition, analysis, or interpretation of data for the work -UKA, EDB. Drafting the work and revising it critically for important intellectual content UKA, EDB. Final approval of the version to be published -UKA, EDB. Agreement to be accountable for all aspects of the work in ensuring that questions related to the accuracy or integrity of any part of the work are appropriately investigated and resolved-UKA, EDB.

\section{CONFLICTS OF INTEREST}

EDB receives consultancy fees from Novartis. Other than that, both authors declare that they do not have any financial and non-financial conflicts to disclose.

\section{DISCLAIMER}

No part of this review is copied or published elsewhere in whole or in part. 


\section{REFERENCES}

1. Ben-Chetrit E, Levy M. Familial mediterranean fever. Lancet 1998;351(9103):659-64.

2. Xu H, Yang J, Gao W, Li L, Li P, Zhang L, et al. Innate immune sensing of bacterial modifications of Rho GTPases by the Pyrin inflammasome. Nature 2014;513(7517):237-41.

3. Heilig R, Broz P. Function and mechanism of the pyrin inflammasome. Eur J Immunol 2018;48(2):230-8.

4. Shohat M, Halpern GJ. Familial Mediterranean fever-a review. Genet Med 2011;13(6):487-98.

5. Ben-Chetrit E, Touitou I. Familial Mediterranean fever in the world. Arthritis Care Res 2009;61(10):1447-53.

6. Lidar M, Yonath H, Shechter N, Sikron F, Sadetzki S, Livneh A, et al. Incomplete response to colchicine in M694V homozygote FMF patients. Autoimmun Rev 2012;12(1):72-6.

7. Gershoni-Baruch $R$, Brik R, Shinawi M, Livneh A. The differential contribution of MEFV mutant alleles to the clinical profile of familial Mediterranean fever. Eur J Hum Genet 2002;10(2):145-9.

8. Akpolat T, Özkaya O, Özen S. Homozygous M694V as a risk factor for amyloidosis in Turkish FMF patients. Gene 2012;492(1):285-9.

9. Livneh A, Langevitz P, Zemer D, Padeh S, Migdal A, Sohar E, et al. The changing face of familial Mediterranean fever. Semin Arthritis Rhem 1996;26(3):612-27.

10. Gattorno M, Hofer M, Federici S, Vanoni F, Bovis F, Aksentijevich I, et al. Classification criteria for autoinflammatory recurrent fevers. Ann Rheum Dis 2019;78(8):1025-32.

11. Ozen S, Demirkaya E, Erer B, Livneh A, Ben-Chedrit E, Giancane G, et al. EULAR recommendations for the management of familial Mediterranean fever. Ann Rheum Dis 2016;75(4):644-51.

12. Ozen S, Kone-Paut I, Gül A. Colchicine resistance and intolerance in familial mediterranean fever: Definition, causes, and alternative treatments. Semin Arthritis Rheum 2017;47(1):115-120.

13. Özen S, Sag E, Ben-Chetrit E, Gattorno M, Gül A, Hashkes PJ, et al. Defining colchicine resistance/intolerance in patients with familial Mediterranean fever: a modified-Delphi consensus approach. Rheumatology (Oxford) 2020;keaa863. doi:10.1093/rheumatology/keaa863. Online ahead of print.

14. Erden A, Batu ED, Sari A, Sonmez HE, Armagan B, Demir S, et al. Which definition should be used to determine colchicine resistance among patients with familial Mediterranean fever? Clin Exp Rheumatol 2018;36(6 Suppl 115):97-102.

15. Sag E, Akal F, Atalay E, Akca UK, Demir S, Demirel D, et al. Anti-IL1 treatment in colchicine-resistant paediatric FMF patients: real life data from the HELIOS registry. Rheumatology (Oxford) 2020;59(11):3324-9.

16. Keino $\mathrm{H}$, Okada AA. Behçet's disease: global epidemiology of an Old Silk Road disease. Br J Ophthalmol 2007:91(12):1573-4.

17. de Menthon M, Lavalley MP, Maldini C, Guillevin L, Mahr A. HLA-B51/B5 and the risk of Behçet's disease: A systematic review and meta-analysis of case-control genetic association studies. Arthritis Care Res 2009;61(10):1287-96.

18. Koné-Paut I. Behçet's disease in children, an overview. Pediatr Rheumatol Online J 2016;14(1):10.

19. Atmaca L, Boyvat A, Yalçındağ FN, Atmaca-Sonmez P, Gurler A. Behçet disease in children. Ocul Immunol Inflamm 2011;19(2):103-7.

20. Koné-Paut I, Shahram F, Darce-Bello M, Cantarini L, Cimaz R, Gattorno M, et al. Consensus classification criteria for paediatric Behçet's disease from a prospective observational cohort: PEDBD. Ann Rheum Dis 2016;75(6):95864.

21. Alpsoy E, Donmez L, Onder M, Gunasti S, Usta A, Karincaoglu $Y$, et al. Clinical features and natural course of Behçet's disease in 661 cases: a multicentre study. Br J Dermatol 2007;157(5):901-906.

22. Krause I, Uziel Y, Guedj D, Mukamel M, Harel L, Molad Y, et al. Childhood Behçet's disease: clinical features and comparison with adult-onset disease. Rheumatology (Oxford) 1999;38(5):457-462.

23. Yazici H, Chamberlain M, Tüzün Y, Yurdakul S, Müftüoglu A. A comparative study of the pathergy reaction among Turkish and British patients with Behçet's disease. Ann Rheum Dis 1984;43(1):74-75.

24. Metreau-Vastel J, Mikaeloff $Y$, Tardieu M, Koné-Paut I, Tran T-A. Neurological involvement in paediatric Behçet's disease. Neuropediatrics 2010;41(5):228-234.

25. Gallizzi R, Pidone C, Cantarini L, Finetti M, Cattalini M, Filocamo G, et al. A national cohort study on pediatric Behçet's disease: cross-sectional data from an Italian registry. Pediatr Rheumatol Online J 2017;15(1):84.

26. Desbois A, Wechsler B, Resche-Rigon M, Piette JC, Huong Dle T, Amoura Z, et al. Immunosuppressants reduce venous thrombosis relapse in Behçet's disease. Arthritis Rheum 2012;64(8):2753-60. 
27. Ozen S. The "other" vasculitis syndromes and kidney involvement. Pediatr Nephrol 2010;25(9):1633-9.

28. Mendes D, Correia M, Barbedo M, Vaio T, Mota M, Gonçalves O, et al. Behçet's disease-a contemporary review. J Autoimmun 2009;32(3-4):178-188.

29. Skef W, Hamilton MJ, Arayssi T. Gastrointestinal Behçet's disease: a review. World J Gastroenterol 2015;21(13):3801-12.

30. Batu ED. Diagnostic/classification criteria in pediatric Behcet's disease. Rheumatol Int 2019;39(1):37-46.

31. International study group for Behcet's disease. Criteria for diagnosis of Behcet's disease. Lancet 1990;335(8697):1078-1080.

32. International Team for the Revision of the International Criteria for Behcet's Disease. Revision of the International Criteria for Behcet's disease (ICBD). Clin Exp Rheumatol. 2006;24(42):14-S15.

33. International Team for the Revision of the International Criteria for Behçet's Disease (ITR-ICBD) The International Criteria for Behçet's Disease (ICBD): a collaborative study of 27 countries on the sensitivity and specificity of the new criteria. J Eur Acad Dermatol Venereol 2014;28(3):338-347.

34. Yıldız M, Köker O, Adrovic A, Şahin S, Barut K, Kasapçopur Ö. Pediatric Behçet's disease-clinical aspects and current concepts. Eur J Rheumatol 2019;7(Suppl 1):1-10.

35. Hatemi G, Melikoglu M, Tunc R, Korkmaz C, Turgut Ozturk B, Mat C, et al. Apremilast for Behçet's syndromea phase 2, placebo-controlled study. N Engl J Med 2015;372(16):1510-1518.

36. Balcı-Peynircioğlu B, Kaya-Akça Ü, Arıcı ZS, Avcı E, Akkaya-Ulum ZY, et al. Comorbidities in familial Mediterranean fever: analysis of 2000 genetically confirmed patients. Rheumatology (Oxford) 2020;59(6):13721380.

37. Touitou I, Magne X, Molinari N, Navarro A, Quellec AL, Picco P, et al. MEFV mutations in Behçet's disease. Hum Mutat 2000;16(3):271-272.

38. Atagunduz P, Ergun T, Direskeneli H. MEFV mutations are increased in Behçet's disease (BD) and are associated with vascular involvement. Clin Exp Rheumatol 2003;21(4 Suppl 30):35-37.

39. Rabinovich E, Shinar Y, Leiba M, Ehrenfeld M, Langevitz P, Livneh A. Common FMF alleles may predispose to development of Behcet's disease with increased risk for venous thrombosis. Scand J Rheumatol 2007;36(1):4852.

40. Schwartz T, Langevitz P, Zemer D, Gazit E, Pras M, Livneh A. Behçet's disease in Familial Mediterranean fever: characterization of the association between the two diseases. Semin Arthritis Rheum 2000;29(5):286-295.

41. Akpolat T, Yilmaz E, Akpolat I, Dilek M, Karagoz F, Balci B, et al. Amyloidosis in Behcet's disease and familial Mediterranean fever. Rheumatology (Oxford) 2002;41(5):592-593.

42. Özen S, Batu ED, Demir S. Familial Mediterranean fever: recent developments in pathogenesis and new recommendations for management. Front Immunol 2017;8:253.

43. Mege J, Dilsen N, Sanguedolce V, Gul A, Bongrand P, Roux H, et al. Overproduction of monocyte derived tumor necrosis factor alpha, interleukin (IL) 6, IL-8 and increased neutrophil superoxide generation in Behcet's disease. A comparative study with familial Mediterranean fever and healthy subjects. J Rheumatol 1993;20(9):1544-1549.

44. Vitale A, Rigante D, Lopalco G, Selmi C, Galeazzi M, lannone F, et al. Interleukin-1 inhibition in Behçet's disease. Isr Med Assoc J 2016;18(3-4):171-176.

45. Sakamoto N, Sekine H, Kobayashi H, Sato Y, Ohira H. Association of the toll-like receptor 9 gene polymorphisms with behcet's disease in a Japanese population. Fukushima J Med Sci 2012;58(2):127-135.

46. Kirino Y, Zhou Q, Ishigatsubo Y, Mizuki N, Tugal-Tutkun I, Seyahi E, et al. Targeted resequencing implicates the familial Mediterranean fever gene MEFV and the toll-like receptor 4 gene TLR4 in Behçet disease. Proc Nat Acad Sci U S A 2013;110(20):8134-8139.

47. Liang L, Tan X, Zhou Q, Zhu Y, Tian Y, Yu H, et al. IL-1 $\beta$ Triggered by Peptidoglycan and Lipopolysaccharide through TLR2/4 and ROS-NLRP3 Inflammasome-Dependent Pathways Is Involved in Ocular Behçet's Disease. Invest Ophthalmol Vis Sci 2013;54(1):402-414.

48. Kim EH, Park M-J, Park S, Lee E-S. Increased expression of the NLRP3 inflammasome components in patients with Behçet's disease. J Inflamm 2015;12:41.

49. Ozen S, Eroglu FK. Pediatric-onset Behçet disease. Curr Opin Rheumatol 2013;25(5):636-642.

50. Fabiani C, Vitale A, Rigante D, Emmi G, Lopalco G, Di Scala G, et al. The presence of uveitis is associated with a sustained response to the interleukin (IL)-1 inhibitors anakinra and canakinumab in Behçet's disease. Ocul Immunol Inflamm 2020;28(2):298-304.

51. Cantarini L, Vitale A, Scalini P, Dinarello CA, Rigante D, Franceschini R, et al. Anakinra treatment in drug-resistant Behcet's disease: a case series. Clin Rheumatol 2015;34(7):1293-1301. 
52. Batu ED, Ozen S. Implications of COVID-19 in pediatric rheumatology. Rheumatol Int 2020;40(8):1193-1213.

53. Espinosa G, Araujo O, Amaro S, Bodro M, Moreno PJ, Moreno R, et al. COVID-19 and Behçet's disease: clinical case series. Ann Rheum Dis 2020;annrheumdis-2020-217778. doi: 10.1136/annrheumdis-2020-217777. Online ahead of print.

54. Brito CA, Paiva JG, Pimentel FN, Guimarães RS, Moreira MR. COVID-19 in patients with rheumatological diseases treated with anti-TNF. Ann Rheum Dis 2020;annrheumdis-2020-218171. doi: 10.1136/annrheumdis2020-218171. Online ahead of print.

55. Thng ZX, De Smet MD, Lee CS, Gupta V, Smith JR, McCluskey PJ, et al. COVID-19 and immunosuppression: a review of current clinical experiences and implications for ophthalmology patients taking immunosuppressive drugs. Br J Ophthalmol 2021;105(3):306-310.

56. Bourguiba R, Delplanque M, Vinit C, Ackermann F, Savey L, Grateau G, et al. Clinical course of COVID-19 in a cohort of 342 familial Mediterranean fever patients with a long-term treatment by colchicine in a French endemic area. Ann Rheum Dis 2020;annrheumdis-2020-218707. doi: 10.1136/annrheumdis-2020-218707. Online ahead of print.

57. Kobak S. COVID-19 infection in a patient with FMF: does colchicine have a protective effect? Ann Rheum Dis 2020;annrheumdis-2020-217882. doi: 10.1136/annrheumdis-2020-217882. Online ahead of print.

58. Chung LK, Park YH, Zheng Y, Brodsky IE, Hearing P, Kastner DL, et al. The Yersinia Virulence Factor YopM Hijacks Host Kinases to Inhibit Type III Effector-Triggered Activation of the Pyrin Inflammasome. Cell Host Microbe 2016;20(3):296-306.

59. Batu ED. A hypothetical role for plague in the selection of MEFV mutation carriers in the Mediterranean area. Cent Asian J Med Hypotheses Ethics 2020;1(1):55-59.

60. Scarsi M, Piantoni S, Colombo E, Airo P, Richini M, Miclini M, et al. Association between treatment with colchicine and improved survival in a single-centre cohort of adult hospitalised patients with COVID-19 pneumonia and acute respiratory distress syndrome. Ann Rheum Dis 2020;79(10):1286-1289.

61. Reyes AZ, Hu KA, Teperman J, Wampler Muskardin TL, Tardif JC, Shah B, et al. Anti-inflammatory therapy for COVID-19 infection: the case for colchicine. Ann Rheum Dis 2020;annrheumdis-2020-219174. doi: 10.1136/annrheumdis-2020-219174. Online ahead of print. 


\section{ОТБАСЫ МЕДИТРАНИЯЛЫҚ ҚЫЗЫЛЫҚ ЖӘНЕ АРА АУРУЫ АРАСЫНДАҒЫ ҰҚСАСТЫҚТАР МЕН АЙЫРМАШЫЛЫҚТАР}

\section{Түйіндеме}

Отбасы медитраниялық қызылық (ОМқ) - көбінесе Шығыс Жерорта теңіз аумағындағы халқына зақым келтіретін, ең таралған моногендік аутоқабыну ауру. Бехчет ауруы (БА) полигендік аутоқабыну ауруларға жатады, бұл барлық түрдегі және өлшемді қан тамырларын зақымдаушы жүйелік васкулит болып саналады. Бұл мақаланың мақсаты ОМқ мен БА арасындағы ұқсастықтар мен айырмашылықтарды қарастыру болып табылады. Қиыр Шығыстан Жерорта теңіздік алабына дейін созылған ежелгі Жібек жолы аймағында БА жиі кездеседі. Қазіргі таңда ОМҚ мен БА арасындағы байланысты зерттеуге арналған зерттеулер бар. MEd Mediterranean FeVer (MEFV) генінің мутациясынан ОМҚ туындайтыны айқындалған, сондай-ақ БА шалдыққан емделушілерде MEFV гені мутациясының жоғарғы жиілігі байқалады. ОМҚ мен БА-да біршама жалпы эпидемиологиялық және патофизиологиялық сипаттамалары болғанымен, нозология мәліметтерінде бір-бірінен бірқатар ерекшеленетін клиникалық белгілері бар. Тері-шырышты көріністер, әсіресе ауыз қуысындағы қайталамалы жара БА-ға шалдыққан емделушілердің ең жиі белгісі болып табылады, ал сероздық қабынумен қоса өтетін безгек ОМқ шалдыққан емделушілердің негізгі клиникалық көрінісі болып саналады.

Түйінді сөздер: Отбасы медитраниялық қызылық, Бехчет ауруы, MEFV гені, COVID-19

Дәйексөз үшін: Бату Е., Акча У. Отбасы медитраниялық қызылық және ара ауруы арасындағы ұқсастықтар мен айырмашылықтар. Медициналық гипотеза мен этиканың Орта Азиялық журналы. 2021; 2 (1): 43-50. https:// doi.org/10.47316/ cajmhe.2021.2.1.07

\section{СХОДСТВА И РАЗЛИЧИЯ МЕЖДУ СЕМЕЙНОЙ СРЕДИЗЕМНОМОРСКОЙ ЛИХОРАДКОЙ И БОЛЕЗНЬЮ БЕХЧЕТА}

\section{Резюме}

Семейная средиземноморская лихорадка (ССЛ) - наиболее распространенное моногенное аутовоспалительное заболевание, поражающее преимущественно население, проживающее в регионе Восточного Средиземноморья. Болезнь Бехчета (ББ) относится к полигенным аутовоспалительным заболеваниям, это системный васкулит, поражающий кровеносные сосуды всех типов и размеров. Цель данной статьи заключается в рассмотрении сходств и различий между ССЛ и ББ. ББ часто встречается на территории древнего Шелковом пути, простирающейся от Дальнего Востока до Средиземноморского бассейна. На данный момент есть исследования, посвященные изучению связи между ССЛ и ББ. Было выявлено, что ССЛ вызывается мутациями гена MEd Mediterranean FeVer (MEFV), у пациентов с ББ также отмечается повышенная частота мутаций гена MEFV. Хотя ССЛ и ББ имеют некоторые общие эпидемиологические и патофизиологические характеристики, данные нозологии имеют ряд отличающихся друг от друга клинических признаков. Кожно-слизистые проявления, особенно рецидивирующие язвы в полости рта, являются наиболее частым симптомом у пациентов с ББ, тогда как лихорадка, сопровождающаяся серозным воспалением, является основным клиническим проявлением у пациентов с ССЛ.

Ключевые слова: Семейная средиземноморская лихорадка, болезнь Бехчета, ген MEFV, COVID-19 Для цитирования: Бату Е., Акча У. Сходства и различия между семейной средиземноморской лихорадкой и болезнью Бехчета. Центральноазиатский журнал медицинских гипотез и этики. 2021; 2 (1): 43-50. https:// doi.org/10.47316/cajmhe.2021.2.1.07 